\title{
WORKSHOP MENUMBUHKAN MINAT BACA DAN PENANGANAN KESULITAN MEMBACA ANAK DI PERUMAHAN GRAHA INDAH SAMARINDA
}

\author{
Nurul Hikmah, Siska Oktaviani \\ Universitas Widya Gama Mahakam Samarinda \\ e-mail: nuruluwgm@gmail.com
}

\begin{abstract}
Abstract The purpose of this activity is to provide guidance and understanding to the community (parents and children) about the importance of fostering interest in reading books and handling reading difficulties in children; Assisting the University in formulating policies, plans and programs related to community service activities, whether carried out by lecturers or students; Apply and develop science; as well as collaborating in the field of community service. However, there are still some obstacles, namely mothers need mentoring facilities, such as mobile libraries and sustainable tutors for their children. The targets of this community service program are to foster interest in reading, improve reading skills and help deal with reading difficulties in children. Based on the observations, it can be seen that the service activities that have been carried out can be said to be quite successful. This was shown by the positive response from mothers and children who enthusiastically participated in the workshop until it was finished. This workshop activity has been carried out. With 30 participants, consisting of parents and children. This community service is in the form of a workshop or gradual guidance consisting of the planning, preparation, implementation and evaluation stages. This activity is carried out with face-to-face events and reading practices that go well and smoothly.
\end{abstract}

Keywords: Interest, Reading, Handling Reading Difficultie 


\begin{abstract}
ABSTRAK
Abstrak Tujuan kegiatan pengabdian ini adalah memberikan bimbingan dan pemahaman kepada masyarakat (orangtua dan anak) tentang pentingnya menumbuhkan minat membaca buku dan penanganan kesulitan membaca pada anak; Membantu Universitas dalam menyusun kebijakan, perencanaan dan program yang berkaitan dengan kegiatan pengabdian kepada masyarakat, baik yang dilakukan oleh dosen maupun mahasiswa; Menerapkan dan mengembangkan ilmu pengetahuan; serta bekerjasama dalam bidang pengabdian kepada masyarakat. Namun masih ada beberapa kendala yaitu ibu-ibu memerlukan fasilitas pendampingan misalnya perpustakaan keliling dan tutor berkelanjutan untuk anak-anaknya. Sasaran dalam program pengabdian kepada masyarakat ini adalah untuk menumbuhkan minat baca, meningkatkan kemampuan membaca dan membantu menangani kesulitan membaca pada anak. Berdasarkan hasil pengamatan terlihat kegiatan pegabdian yang telah dilaksanakan ini dapat dikatakan cukup berhasil. Hal tersebut ditunjukkan dengan adanya respon yang positif dari ibu-ibu dan anak-anak dengan bersemangat mengikuti workshop hingga selesai. Kegiatan workshop ini telah dilaksanakan. Dengan jumlah peserta 30 orang, yang terdiri dari orang tua dan anak-anak. Pengabdian pada masyarakat ini berupa workshop atau bimbingan bertahap yang terdiri atas tahap perencanaan, persiapan, tahap pelaksanaan dan tahap evaluasi. Kegiatan ini dilaksanakan dengan acara tatap muka dan praktik membaca berjalan dengan baik dan lancar.
\end{abstract}

Kata Kunci : Minat, Membaca, Penanganan Kesulitan Membaca 


\section{A. PENDAHULUAN}

Di era global ini, dunia pendidikan semakin maju dan berkembang. Pendidikan menjadi salah satu acuan penilaian suatu negara. Suatu negara dapat dikatakan berkembang jika dilihat dari indeks pendidikan dan jumlah buta huruf suatu negara. Rendahnya minat baca pada kalangan masyarakat Indonesia merupakan masalah besar yang belum terpecahkan. Rendahnya minat baca sangat erat hubungannya dengan rendahnya mutu Sumber Daya Manusia (SDM), karena membaca adalah salah satu cara untuk meningkatkan ilmu pengetahuan dan mutu atau kualitas diri individu.

Minat sangat penting bagi manusia, karena minat adalah salah satu faktor yang memotivasi dan menolong manusia untuk mencapai tujuannya. Minat atau perhatian merupakan pemusatan atau konsentrasi dari seluruh aktivtas individu yang ditujukan kepada suatu atau sekumpulan objek. Objek yang menjadi perhatian pasti akan disadari oleh manusia itu sendiri, dan akan sangat jelas bagi manusia yang bersangkutan.

Salah satu hal yang menyebabkan demikian yaitu minat baca anak di perumahan graha indah masih rendah. Mulai kalangan anak sekolah dasar sampai jenjang perguruan tinggi. Kebiasaan ini terlihat dalam kebiasaannya sehari-sehari di rumah dan di sekolah. Kebiasaan membaca harus mulai diajarkan di tingkat pendidikan anak usia dini. Membaca merupakan kegiatan melihat, mengeja, mempelajari, memahami untuk memperoleh informasi seperti contohnya membiasakan anak dalam hal membaca buku, koran, majalah, internet, televisi.Agar membaca menjadi suatu kegemaran semua orang ,perlu jadikan kegiatan membaca adalah hal yang dibiasakan sejak dini dan menyenangkan. Oleh sebab itu, kita sebagai orangtua harus mengajarkan dan membimbing strategi meningkatkan minat baca kepada anak-anak. 
Membaca juga merupakan kegiatan positif yang sangat bermanfaat bagi anak. Dengan membaca dapat mempengaruhi perkembangan pikir anak. Membaca dapat memperbanyak jaringan ilmu pengetahuan yang didapatkan oleh anak. Semakin banyak jaringan otak yang terbentuk, menjadikan otak anak semakin cepat respon/tanggap. Jadi, membaca tidak saja memperoleh pengetahuan umum pada anak, membaca akan memberikan pengetahuan anak tentang dirinya. Akan tetapi pada faktanya yang dilihat pada anak perumahan graha indah, kegiatan membaca kurang digemari anak-anak dan anak-anak yang masih usia sekolah dasar memiliki rasa malas dan bosan dalam membaca, karena mereka masih suka berkumpul dengan teman-temannya bermain bersama, belum fokus dan belum memusatkan perhatian.

Minat baca dipengaruhi oleh faktor eksternal dan faktor internal. Mumpuni (2019) menjelaskan bahwa faktor yang menjadi penghambat anak kurang berminat untuk berlatih membaca sangat banyak, beberapa diantaranya yaitu faktor lingkungan. Faktor eksternal yang mempengaruhi minat baca anak yaitu faktor dosen, lingkungan dan fasilitas. Ruslan (2019) juga menjelaskan bahwa rendahnya minat baca siswa, disebabkan karena siswa selalu malas, menganggap membaca membosankan dan banyak siswa yang kurang paham pentingnya membaca buku. Anggraini (2020) mengungkapkan bahwa orang tua memegang peran penting, sebagai orang tua harus sadar dan bisa melaksanakannya dengan baik, tetapi pada kenyataannya banyak orang tua yang masih belum sadar akan pentingnya menanamkan minat baca pada anak. Windrawati (2020) juga mengungkap bahwa faktor yang menghambat pembaca permulaan siswa di kelas I adalah faktor anak yang belum mengenal huruf (daya ingat yang lemah) dan kurangnya bimbingan orang tua di rumah. Mardika (2017) juga menjelaskan bahwa kesulitan membaca, menulis dan berhitung dipengaruhi oleh beberapa 
faktor yaitu faktor lingkungan keluarga perhatian orang tua, pendampingan dan pengawasan yang dianggap sangat penting, mempengaruhi minat, motivasi siswa dan lingkungan siswa pada proses pembelajaran. Pramesti (2018) juga menjelaskan bahwa faktor-faktor penghambat membaca permulaan pada siswa kelas 1 SD Negeri 1 Wonorejo diantaranya adalah: faktor intelektual, lingkungan, kurangnya motivasi dari pihak keluarga dan kurangnya minat membaca siswa yang rendah.

Irna (2019) mengungkapkan salah satu tahapan yang dapat dilaksanakan yaitu dengan kegiatan literasi keluarga. Kegiatan yang dilakukan dalam program literasi keluarga yaitu kegiatan orang tua membacakan buku kepada anak baik di rumah ataupun di sekolah, kegiatan membuat pojok baca di rumah, kegiatan berkunjung ke perpustakaan atau ke toko buku. Amka (2017) juga mengungkapkan bahwa peningkatan minat membaca bagi warga sekolah yang merupakan faktor penentu bagi kesuksesan siswa dalam mengikuti pendidikan di sekolah melalui strategi meningkatkan minat baca serta dengan mengekplorasi peran tenaga pendidik dalam menumbuhkan minat baca. Windrawati (2020) menjelaskan bahwa solusi untuk mengatasi kesulitan dalam membaca permulaan yaitu, guru kelas lebih mengutamakan, memberikan pelatihan khusus anak-anak yang mengalami kesulitan, adanya hubungan kerjasama yang baik antara guru dan orang tua siswa selalu membimbing anak dalam belajar membaca, minat siswa harus dikembangkan dan dilatih terus menerus. Pramesti (2018) juga menjelaskan bahwa solusi yang bisa digunakan untuk mengatasi kesulitan dalam membaca permulaan adalah guru kelas lebih memprioritaskan anakanak yang mengalami kesulitan, harus memberikan perhatian khusus kepada anak-anak yang mengalami kesulitan, memiliki hubungan kerjasama yang baik antara guru kelas dan orang tua siswa, orang tua harus lebih 
memperhatikan, memantau anak dalam belajar membaca dan minat siswa harus dikembangkan dan dilatih terus menerus.

\section{B. PELAKSANAAN DAN METODE}

Kegiatan ini dilaksanakan di jalan pangeran suryanata komplek graha indah blok M.No.1 Samarinda. Dosen PGSD UWGM Samarinda telah mengadakan Workshop Menumbuhkan Minat Baca dan Penanganan Kesulitan Membaca pada Anak. Sasaran pengabdian masyarakat ini adalah orangtua dan anak-anak. Metode yang digunakan dalam Pengabdian pada Masyarakat ini berupa workshop atau bimbingan bertahap yang terdiri atas tahap perencanaan, persiapan, tahap pelaksanaan (metode penyuluhan dan pelatihan), tahap evaluasi.

\section{Tahap Perencanaan}

Tahap pertama merupakan tahap perencanaan kegiatan yang akan dilakukan. Perencanaan disusun oleh masyarakat, tim pengabdian sebagai fasilitator.

2. Tahap Persiapan

Tahap kedua merupakan tahap persiapan. Kegiatan ini yang dilakukan pada tahap persiapan pelaksanaan kegiatan adalah sebagai berikut :

a. Mengadakan koordinasi dengan mitra terkait, dalam hal ini akan berdiskusi dengan ketua RT 53 di Perumahan Graha Indah Samarinda dan wilayah tersebut yang akan menjadi tempat kegiatan workshop;

b. Mengamati (observasi) tentang pemahaman anak dalam membaca buku fiksi dan nonfiksi;

c. Mewawancarai orangtua dan anak tentang membaca buku fiksi dan nonfiksi. 
3. Tahap Pelaksanaan

Tahap ketiga merupakan tahap pelaksanaan. Pelaksanaan Workshop akan dilaksanakan dalam dua tahap kegiatan, yaitu :

a. Pemahaman tentang pengertian, manfaat, taktik/strategi menumbuhkan minat membaca buku fiksi dan nonfiksi, serta cara mengatasi kesulitan belajar membaca.

b. Penerapan membaca buku dan mengatasi kesulitan belajar membaca:

- Memilih buku fiksi dan nonfiksi yang sesuai dengan karakteristik anak/siswa;

- Menyusun strategi/langkah membaca buku dan menerapkan cara mengatasi kesulitan membaca.

4. Evaluasi

Tahap keempat merupakan tahap pelaksanaan evaluasi dilaksanakan setiap akhir kegiatan pada setiap tahap kegiatan untuk membahas keterlaksanaan workshop, hambatan yang dihadapi dan solusi yang ditawarkan.

\section{HASIL DAN PEMBAHASAN}

Kegiatan pengabdian masyarakat ini telah dilaksanakan. Kegiatan ini dilaksanakan di jalan pangeran suryanata komplek graha indah blok M.No.1 Samarinda. Kegiatan ini diundang ada 50 orang dan yang menghadiri yaitu ibu-ibu dan anak-anak yang berjumlah 30 orang. Pengabdian pada Masyarakat ini berupa workshop atau bimbingan bertahap yang terdiri atas tahap perencanaan, persiapan, tahap pelaksanaan (metode penyuluhan dan pelatihan), tahap evaluasi. Kegiatan ini dilaksanakan dengan acara tatap muka dan praktik membaca berjalan dengan baik dan lancar. Kegiatan pegabdian yang telah dilaksanakan ini dapat dikatakan cukup berhasil. Hal tersebut 
ditunjukan dengan adanya respon yang positif dari ibu-ibu dan anak-anak dengan bersemangat mengikuti workshop hingga selesai. Adanya pelaksanaan pengabdian ini sangat bermanfaat bagi ibu-ibu dan anak-anak.

Sebelum dilakukannya kegiatan pengabdian masyarakat ini, telah dilakukan tahap pertama yaitu tahap perencanaan. Untuk memulai kegiatan, tim pengabdian menghubungi Ketua RT untuk menjelaskan maksud kegiatan pengabdian. Ketua RT kemudian menyambut kegiatan ini dengan baik, menyatakan bahwa anak-anak dan orangtua akan ikut dengan senang hati ikut terlibat pada kegiatan ini. Perencanaan ini disusun oleh masyarakat termasuk merencanakan waktu, tempatnya dan konsumsinya. Tim pengabdian sebagai fasilitator. Kemudian kegiatan yang dilakukan pada tahap persiapan pelaksanaan kegiatan adalah mengadakan koordinasi dengan mitra terkait, dalam hal ini akan berdiskusi dengan ketua RT 53 di Perumahan Graha Indah Samarinda dan wilayah tersebut yang menjadi tempat kegiatan workshop, mengamati (observasi) tentang pemahaman anak dalam membaca buku fiksi dan nonfiksi, mewawancarai ibu-ibu dan anak tentang membaca buku fiksi dan nonfiksi.

Persiapan dengan cara survei dan wawancara terhadap beberapa responden anak dan ibu-ibu di graha indah untuk mengetahui minat baca anak. Di Graha Indah ini termasuk komplek yang terdiri dari kalangan orangorang bekerja yang tinggal disana. Sehingga kurang perhatian orangtua, karena kerja mulai pagi sampai sore, hanya malam bisa membimbing anak dalam belajar. Orangtua tersebut hanya mengharapkan bimbingan dari guru di sekolah. Dari hasil survei didapatkan data bahwa kegiatan ini sangat perlu untuk dilaksanakan. 


\section{Gambar 1.}

Tim Pengabdian Menjelaskan Materi

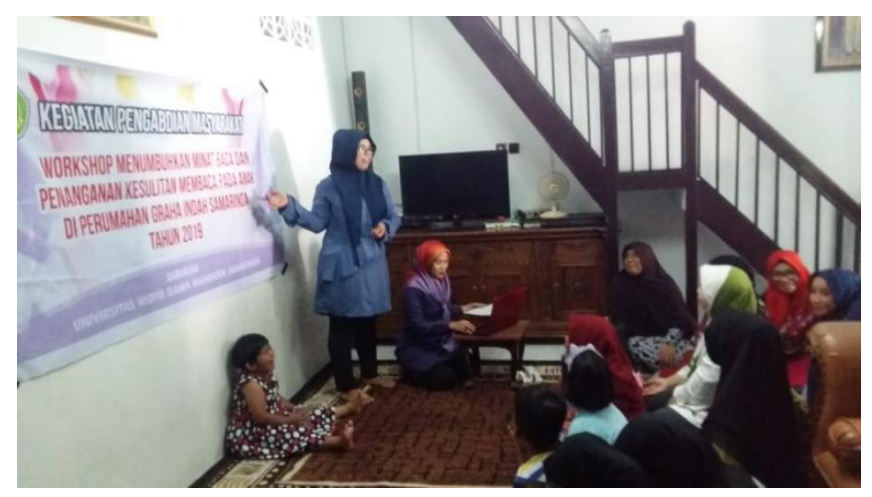

Kegiatan yang terealisasi dalam pengabdian kepada masyarakat di Perumahan Graha Indah yaitu Workshop Menumbuhkan Minat Baca dan Penanganan Kesulitan Membaca Pada Anak. Dalam merealisasikan workshop ini, tim pengabdian bekerja sama dengan ibu-ibu dan anak-anak dalam menyelenggarakan sampai terlaksananya kegiatan ini dengan lancar. Bantuan yang diberikan oleh tim pengabdian berupa buku. Pada hari pelaksanaan workshop yang dipimpin oleh tim pengabdian dan dihadiri oleh ibu-ibu dan anak-anak. Ibu-ibu dan anak-anak dengan sungguh-sungguh memperhatikan dan menjawab pertanyaan dengan penuh semangat. Acara workshop ini dilengkapi dengan minuman, makanan berat dan makanan ringan untuk peserta workshop.

Kegiatan workshop ini memperlihatkan bahwa kegiatan ini dapat diterima oleh masyarakat setempat dan memperoleh respon yang positif. Bahkan, ibu-ibu dan anak-anak sesungguhnya dapat menjadi agen promosi pendidikan yang mengajak masyarakat sekitar untuk membiasakan membaca buku, menjelaskan tentang cara menumbuhkan minat baca dan mengatasi kesulitan membaca.

Pelaksanaan Workshop akan dilaksanakan dalam dua tahap kegiatan, yaitu : 
1. Pemahaman tentang pengertian, manfaat, taktik/strategi menumbuhkan minat membaca buku fiksi dan nonfiksi, serta cara mengatasi kesulitan belajar membaca.

2. Penerapan membaca buku dan mengatasi kesulitan belajar membaca.

\section{Gambar 2.}

Diskusi Bersama Peserta Workshop

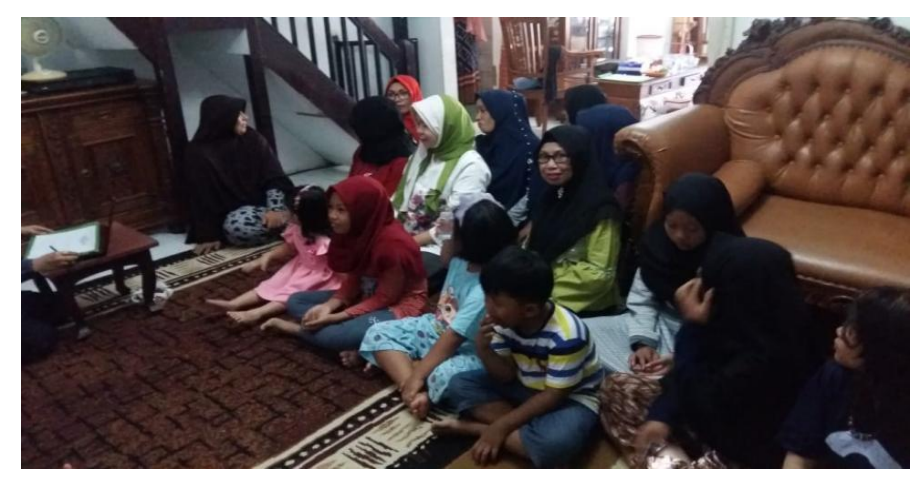

Setelah pelaksanaan workshop, ibu-ibu dan anak-anak berkumpul yang bertujuan untuk mengevaluasi kegiatan yang telah dilaksanakan. Dari diskusi yang diadakan, ibu-ibu dan anak-anak berharap agar kegiatan workshop dapat berkelanjutan. Masyarakat memiliki kemauan untuk membaca buku baik fiksi maupun nonfiksi.

\section{Gambar 3.}

Foto Bersama Setelah Workshop

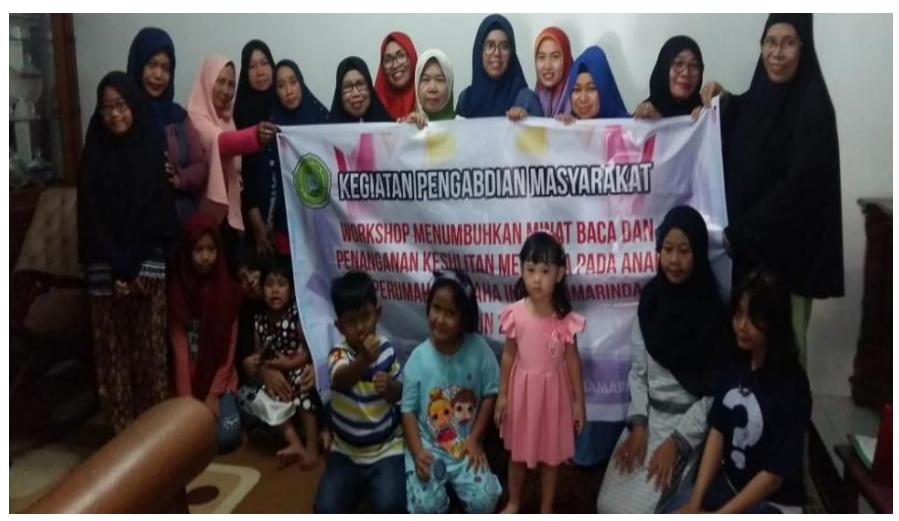

WORKSHOP MENUMBUHKAN MINAT BACA DAN PENANGANAN KESULITAN MEMBACA ANAK... 
Hal yang paling penting adalah ibu-ibu memerlukan fasilitas pendampingan misalnya perpustakaan keliling dan tutor untuk anakanaknya. Dari evaluasi pengabdian ini, maka diperoleh informasi bahwa pada umumnya peserta menyatakan memperoleh pengetahuan penting dan pengalaman berharga yang dapat dijadikan bekal. Menumbuhkan minat baca kepada anak seharusnya diterapkan sejak kecil. Mulai anak sudah hapal huruf. Glenn Doman dalam bukunya yang berjudul "Mengajarkan Bayi Anda Membaca" menjelaskan mulai anak usia 18 bulan sampai 4 tahun mempunyai "rasa ingin mengetahui" yang sangat tinggi. Rasa ingin mengetahui tersebut tidak hanya terlihat saat melihat simbol yang terdapat pada buku. Para orang tua seharusnya mempersiapkan bacaan di rumah, seperti koran, majalah, kamus dan buku ilmu pengetahuan.

Di rumah, orang tua harus menjadi teladan untuk anaknya, contoh dengan rajin membaca sebagai percontohan anak-anaknya. Tidak ada yang lebih penting agar bisa mensukseskan akademik seseorang, selain menjadi pembaca yang baik. Orang tua bisa mengenal anak-anak mereka dengan baik dan bisa membagi waktu dan perhatian untuk membimbing anak-anak mereka agar bisa sukses dalam membaca. Langkah-langkah yang ditempuh untuk membantu anak menjadi pembaca yang lebih efektif, yaitu : 1) Menyediakan waktu luang dalam membacakan buku untuk anak setiap hari.

2) Mengelilingi anak-anak dengan berbagai macam buku bacaan. 3) Membuat kegiatan membaca dilakukan bersama keluarga. Kemudian menyediakan waktu setiap hari 15 sampai 30 menit untuk seluruh anggota keluarga membaca bersama-sama dengan tenang dan santai. Dengan anak melihat orangtuanya membaca dapat mempengaruhi anak untuk ikut membaca. Hanya dengan latihan 15 menit per hari cukup untuk membangkitkan minat baca anak. 4) Memberikan dukungan pada berbagai 
aktivitas membaca anak. 5) Membiasakan pergi ke perpustakaan. 6) Rajin mengikuti dalam kemajuan membaca anak. 7) Butuh perhatian dari orang tua, apakah anak-anak ada mempunyai masalah dalam membaca buku bacaannya. 8) Mencari bantuan secepatnya jika ada masalah dalam membaca. 9) Menerapkan cara yang bervariasi untuk menolong anak. 10) Memperlihatkan antusias orangtua ketika anak membaca buku bacaannya.

\section{KESIMPULAN}

Pelaksanaan kegiatan pengabdian ini secara keseluruhan berhasil. Keberhasilan ini ditunjukkan antara lain : materi workshop yang diberikan sesuai dengan kebutuhan ibu-ibu dan anak. Hal ini terlihat dari respon positif yang diberikan oleh peserta. Peserta menambah wawasan dan memberi manfaat bagi peserta. Hal ini diperlihatkan dengan antusiasme sejak awal sampai selesai kegiatan pengabdian ini.

Setelah dilaksanakannya pengabdian ini, bisa ditarik kesimpulan bahwa ternyata ibu-ibu dan anak-anak di perumahan graha indah sangat membutuhkan dan mengharapkan bimbingan lebih lanjut dari tim pengabdian. Minat baca anak sangat rendah. Mereka lebih bahagia mengisi kegiatan setiap harinya dengan hiburan pada acara di televisi, warnet, mall, game dan tempat hiburan lainnya dibandingkan mengisi kegiatan dengan membaca buku.

\section{E. UCAPAN TERIMA KASIH}

Tim Pengabdian mengucapkan Terima Kasih kepada Lembaga Penelitian dan Pengabdian kepada Masyarakat (LPPM) Universitas Widya Gama Mahakam (UWGM) Samarinda yang telah memberikan bantuan dana untuk kegiatan pengabdian ini. 


\section{DAFTAR PUSTAKA}

Amka. (2017). Menumbuhkan Minat Membaca dan Menulis Peserta Didik, Universitas Lambung Mangkurat, 4 (2), Jurnal Ilmiah Pendidikan dan Sosial.

Anggraini. (2020). Pemanfaatan Gadget dalam Meningkatkan Minat Baca Anak di Keluarga, Universitas Airlangga, 10 (2), Jurnal Perpustakaan Universitas Airlangga.

Irna. (2019). Menumbuhkan Minat Baca Anak Usia Dini Melalui Implementasi Literasi Keluarga, STKIP Muhammadiyah Bogor, 1 (1), Fascho Kajian Pendidikan dan Sosial Kemasyarakatan.

Mardika (2017). Analisis Faktor-faktor Kesulitan Membaca Menulis dan Berhitung Siswa Kelas 1 SD, SD N Pancurendang, Banyumas, 10 (1), Jurnal Dinamika Pendidikan Dasar.

Mumpuni, A. (2019). Analisa Faktor yang Mempengaruhi Minat Baca Mahasiswa PGSD, Universitas Muhadi Setiabudi, 3 (2), Jurnal Dwija Cendekia: Jurnal Riset Pedagogik.

Pramesti, F. (2018). Analisis Faktor-faktor Penghambat Membaca Permulaan pada Siswa Kelas 1 SD , STKIP PGRI Tulungagung, 2 (3), Jurnal Ilmiah Sekolah Dasar .

Ruslan. (2019). Pentingnya Meningkatkan Minat Baca Siswa. Universitas PGRI Palembang.

Windrawati. (2020). Analisis Faktor Penghambat Belajar Membaca Permulaan pada Siswa Kelas I SD Inpres 141 Matalamagi Kota Sorong. Universitas Pendidikan Muhammadiyah Sorong, 2 (1), Jurnal Papeda (Jurnal Publikasi Pendidikan Dasar). 